Syntax Literate: Jurnal Ilmiah Indonesia p-ISSN: 2541-0849

e-ISSN: 2548-1398

Vol. 6, No. 1, Januari 2021

\title{
PENGARUH UKURAN MAKSIMUM AGREGAT TERHADAP KINERJA CAMPURAN LAPIS ASPAL BETON (LASTON)
}

\author{
Miftah Farid
}

Universitas Mataram, Indonesia

Email: miftahfarid3230@yahoo.co.id

\begin{abstract}
This research is conducted to observe the effects of using different maximum aggregate size to the mixture's performance. The type of pavement used is Asphalt Concrete Base (AC-Base). The maximum aggregate sizes are 1" dan 1 1/2". Experiments are conducted using Marshall Method by referring to Bina Marga General Specification 2010 rev. 3 (2013). Observation are conducted to obtain the volumetric parameters, mechanical properties, Indirect Tensile Strength (ITS) and stiffness. The results shows bigger aggregate size resulting in decreasing VIM value, increase in VMA and VFB, bigger MQ, ITS increases, horizontal stiffness tend to increase. Stability and Flow increase on specimen with maximum aggregate 1 1/2" with 10\% aggregate size 1" and decrease on 5\% aggregate 1". Vertical stiffness decreases on specimen using maximum aggregate size 1 1/2" with 10\% aggregate size 1", opposed to that with 5\% aggregate size 1". It can be concluded that specimens using maximum aggregate 1 1/2" with $10 \%$ of aggregate size 1" shows the best performance according to its volumetric and mechanic properties.
\end{abstract}

Keywords: maximum aggregate size; ac-base; marshall; mechanical and volumetric properties of the mixture; indirect tensile strength (ITS); Stiffness

\begin{abstract}
Studi ini dilakukan untuk mengetahui bagaimana penggunaan ukuran agregat maksimum yang berbeda mempengaruhi kinerja campuran akhir. Jenis paving layer yang digunakan berdasarkan komunikasi. Ukuran koleksi maksimal yang digunakan adalah 1 "dan 1 1/2". Pengujian dilakukan dengan menggunakan metode Marshall dan mengacu pada spesifikasi umum bina marga 2010 revisi 3 2013. Pengujian yang dilakukan adalah memeriksa sifat volume, sifat mekanik, kuat tarik tidak langsung (ITS) dan kekakuan. Hasil penelitian menunjukkan bahwa semakin besar ukuran agregat maksimum yang digunakan, semakin rendah nilai VIM, peningkatan VMA, peningkatan VFB, dan semakin besar MQ, semakin besar nilai ITS maka nilai kekakuan horizontal cenderung meningkat. Dalam sampel dengan ukuran maksimum 1 1/2 "(menggunakan 10\% dari total ukuran 1"), stabilitas dan fluiditas meningkat, sedangkan pada sampel dengan ukuran agregat 5\% 1 ", stabilitas dan fluiditas menurun Nilai kekakuan vertikal Untuk spesimen ukuran 1 1/2 "menggunakan ukuran agregat $10 \%$, sedangkan untuk ukuran agregat $11 / 2$ " menggunakan ukuran agregat $5 \% 1$ ", nilai kekakuan vertikal meningkat Besar. Dapat disimpulkan bahwa dari segi volume dan sifat mekaniknya, sampel 10\% dengan ukuran agregat terbesar $11 / 2$ "dan kandungan agregat 1" menunjukkan kinerja terbaik.
\end{abstract}


Kata Kunci: ukuran maksimum agregat; ac-base; marshall; sifat mekanis; volumetrik campuran; indirect tensile strength (ITS); stiffness

Coresponden Author

Email: miftahfarid3230@yahoo.co.id

Artikel dengan akses terbuka dibawah lisensi

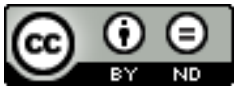

\section{Pendahuluan}

Indonesia merupakan negara agraris besar dengan kekayaan alam yang kaya, terutama sumber daya hayati tropis yang sangat beragam dan unik (Khonado et al., 2019). Indonesia sebagai negara yang menyimpan berbagai kekayaan alam tentunya memiliki banyak potensi Indikasi Geografis untuk selalu dikembangkan Perlindungan bagi Indikasi Geografis merupakan hal yang harus dipandang serius karena merupakan hasil dari karya intelektual untuk menghindari pelanggaran atau penyalahgunaan hak-hak yang timbul dari lahirnya karya intelektual tersebut (Dewi \& Landra, 2019).

Indonesia memiliki sumber daya alam yang melimpah, termasuk sumber daya mineral yang digunakan sebagai bahan baku perkerasan jalan. Masih sedikit pengembangan pemanfaatan sumber daya alam berupa bahan baku perkerasan jalan terutama dalam mengatasi masalah kerusakan perkerasan jalan prematur. (Saleh, 2018).

Media aspal biasanya digunakan untuk pengerasan jalan. Namun dewasa ini kita sering melihat penggunaan media lain selain paving aspal yaitu paving bricks. Paving tile atau ubin lantai merupakan salah satu bahan batu cetak yang terkenal di masyarakat dan banyak digunakan sebagai bahan bangunan gedung dan jalan. Komponen dasar paving tile adalah semen portland, air, agregat halus dan agregat kasar (Gardjito et al., 2018).

Agregat adalah hasil olahan batu alam merupakan komponen utama dari lapisan perkerasan jalan, yaitu memberikan sifat struktural dan memberkan kontribusi sebesar 90 $-95 \%$ terhadap berat atau 70-85\% terhadap volume dari struktur perkerasan jalan, oleh sebab itu sifat agregat sangat mempengaruhi kinerja dari pada perkerasan (Toruan et al., 2013).

Agregat adalah bahan batuan, biasanya didefinisikan sebagai pembentukan kerak keras seperti spons (padat) (Waani, 2013).

Bahan dan material pembentuk lapisan perkerasan jalan adalah agregat sebagai material bahan utama dan aspal sebagai bahan pengikatnya yang bersifat kedap air. Agregat merupakan komponen utama dari lapisan perkerasan jalan yaitu berkisar antara 90 - $95 \%$ berdasarkan presentase beratnya dan berkisar antara 75\% - 85\% berdasarkan persentase volumenya. Dengan demikian keawetan, daya dukung dan mutu perkerasan jalan ditentukan juga dari sifat agregat (Sukirman, S., 2016). Salah satu sifat tersebut adalah ukuran maksimum agregat yang dipakai dalam campuran.

Penggunaan agregat besar memiliki keunggulan stabilitas yang lebih tinggi dan konsumsi aspal yang lebih sedikit. Akan tetapi di sisi lain penggunaan agregat dengan ukuran besar memungkinkan terjadinya kerusakan dini seperti retak dan terbentuknya 
gelombang melintang (Arfan, 2018). Selain itu, diyakini bahwa penggunaan agregat besar di lapangan sulit dilakukan, sehingga terdapat risiko pemisahan, yang mengakibatkan distribusi yang tidak merata antara agregat kasar dan agregat halus dalam campuran, mengakibatkan perubahan gradasi dan kandungannya. Aspal dalam campuran oleh karenanya menurunkan kualitas campuran.

Penelitian ini dilakukan untuk mengetahui bagaimana menggunakan ukuran agregat maksimum yang berbeda mempengaruhi kinerja campuran yang dihasilkan. Jenis lapisan paving yang digunakan adalah alas beton aspal (ac-base).

Dalam penelitian ini digunakan benda uji dengan jenis laston ac-base yang diuji untuk melihat pengaruh yang dihasilkan dari penggunaan ukuran maksimum agregat yang berbeda terhadap parameter volumetrik dan mekanik yang dihasilkan dengan mengacu pada peraturan bina marga 2010 revisi 3 tahun 2013 (Situmorang, 2015). Pada penelitian juga dilakukan pengujian kuat tarik tak langsung dan uji kekakuan sebagai variabel tambahan terhadap penggunaan ukuran maksimum agregat yang berbeda.

\section{Metode Penelitian}

Penelitian dimulai dari persiapan bahan dan alat berupa agregat dan aspal serta alatalat yang diperlukan. Langkah selajutnya adalah pemeriksaan bahan material yang akan digunakan dalam campuran dalam hal ini adalah aspal dan agregat. Pemeriksaan aspal dan agregat mengacu pada spesifikasi bina marga 2010 revisi 32013 untuk menentukan apakah bahan layak untuk digunakan dalam pembuatan campuran atau tidak. Selanjutnya adalah menentukan gradasi tiap ukuran maksimum yang akan digunakan. Pembuatan gradasi ukuran maksimum mengacu pada gradasi laston jenis ac-base pada spesifikasi bina marga 2010 rev 32013.

Dari gradasi yang teah dibuat selanjutnya adalah menentukan kadar aspal rencana dengan menggunakan rumus $\mathrm{Pb}$ untuk mendapatkan besaran kadar aspal optimum. Setelah kadar aspal rencana ditentukan maka selanjutnya adalah membuat variasi kadar aspal rencana dan benda uji dengan variasi kadar aspal rencana tersebut (Rahman et al., 2017). Benda uji yang telah dibuat tadi kemudian diuji untuk mendapatkan nilai volumetrik dan mekanik untuk melihat kadar aspal mana yang memenuhi semua persyaratan sehingga dipilih sebagai kadar aspal optimum. Langkah selanjutnya adalah membuat benda uji dengan kadar aspal optimum dengan variasi ukuran maksimum untuk diuji sifat volumetrik, sifat mekanik, IDT dan stiffnessnya kemudian dianalisa sehingga diambil kesimpulan dari penelitian ini.

\section{Hasil dan Pembahasan}

\section{Pemeriksaan Mutu Bahan}

Dari serangkaian percobaan yang telah dilakukan diketahui kualitas dari agregat dan aspal yang digunakan telah mampu memenuhi persyaratan sesuai dengan peraturan bina marga 2010 revisi III tahun 2013. 


\section{Gradasi Campuran Ukuran Maksimum}

Penentuan proporsi gradasi campuran ukuran maksimum dari tiap ukuran agregat didasarkan pada gradasi yang telah tersedia di spesifikasi bina marga 2010 revisi III tahun 2013 untuk jenis laston ac-base. Untuk lebih jelasnya dapat dilihat di Tabel 1. di bawah.

Tabel 1

Spesifikasi Gradasi Ukuran Maksimum Agregat yang Digunakan

\begin{tabular}{|c|c|c|c|c|c|}
\hline \multicolumn{2}{|c|}{ Saringan } & \multirow{2}{*}{$\begin{array}{c}\begin{array}{c}\text { Spesifikasi } \\
(\% \text { lolos })\end{array} \\
100\end{array}$} & \multirow{2}{*}{$\begin{array}{c}\begin{array}{c}\text { Ukuran } \\
\text { Maksimum A }\end{array} \\
100\end{array}$} & \multirow{2}{*}{$\begin{array}{c}\begin{array}{c}\text { Ukuran } \\
\text { Maksimum B }\end{array} \\
100\end{array}$} & \multirow{2}{*}{$\begin{array}{c}\begin{array}{c}\text { Ukuran } \\
\text { Maksimum C }\end{array} \\
100\end{array}$} \\
\hline $15 "$ & $37,5 \mathrm{~mm}$ & & & & \\
\hline $1 "$ & $25 \mathrm{~mm}$ & $90-100$ & 100 & 95 & 90 \\
\hline $3 / 4 "$ & $19 \mathrm{~mm}$ & $76-90$ & 83 & 83 & 83 \\
\hline $1 / 2 "$ & $12,5 \mathrm{~mm}$ & $60-78$ & 69 & 69 & 69 \\
\hline $3 / 8^{\prime \prime}$ & $9,5 \mathrm{~mm}$ & $52-71$ & 62 & 62 & 62 \\
\hline No. 4 & $4,75 \mathrm{~mm}$ & $35-54$ & 45 & 45 & 45 \\
\hline No. 8 & $2,36 \mathrm{~mm}$ & $23-41$ & 32 & 32 & 32 \\
\hline No. 16 & $1,18 \mathrm{~mm}$ & $13-30$ & 26 & 26 & 26 \\
\hline No. 30 & $0,60 \mathrm{~mm}$ & $10-22$ & 22 & 22 & 22 \\
\hline No. 50 & $0,30 \mathrm{~mm}$ & $6-15$ & 11 & 11 & 11 \\
\hline No. 100 & $0,15 \mathrm{~mm}$ & $4-10$ & 7 & 7 & 7 \\
\hline No. 200 & $\begin{array}{c}0,075 \\
\mathrm{~mm}\end{array}$ & $3-7$ & 5 & 5 & 5 \\
\hline Filler & - & - & - & - & - \\
\hline
\end{tabular}

\section{Kadar Aspal Optimum}

Untuk pembuatan campuran, gradasi yang digunakan berupa gradasi ukuran maksimum $\mathrm{B}$ dengan kadar aspal rencana $(\mathrm{Pb})$ berdasarkan besarnya proporsi agregat kasar $(\mathrm{a})=55 \%$, agregat halus $(\mathrm{b})=40 \%$, dan filler $(\mathrm{c})=5 \%$ dengan nilai konstanta (k) untuk campuran laston $=0,5-1$.

$$
\mathrm{Pb}=0,035(\mathrm{a})+0,045(\mathrm{~b})+0,18(\mathrm{c})+(\text { konstanta }=0,90)
$$

$\mathrm{Pb}=(0,035 * 55)+(0,045 * 40)+(0,18 * 5)+0,90$

$\mathrm{Pb}=5,525 \%$

$\mathrm{Pb} \approx 5,5 \%$ (digunakan)

Kemudian dibuat variasi kadar aspal dengan interval $\mathrm{Pb}-1 \%, \mathrm{~Pb}-0,5 \%, \mathrm{~Pb}$, $\mathrm{Pb}+0,5 \%, \mathrm{~Pb}+1 \%$ sehingga variasi kadar aspal yang dipakai adalah 4,5\%; 5,0\%; $5,5 \% ; 6,0 \%$; dan $6,5 \%$. Untuk melihat kadar aspal optimum dapat dilihat dari tabel penentuan KAO di bawah ini. 
Tabel 2

Penentuan Kadar Aspal Optimum

\begin{tabular}{ccccccc}
\hline Parameter & Syarat & \multicolumn{5}{c}{ Kadar Aspal (\%) } \\
\cline { 3 - 7 } & & $\mathbf{4 , 5}$ & $\mathbf{5 , 0}$ & $\mathbf{5 , 5}$ & $\mathbf{6 , 0}$ & $\mathbf{6 , 5}$ \\
\hline VMA & Min. 13\% & 12,187 & 12,853 & 13,856 & 13,773 & 13,577 \\
\hline VIM & $\mathbf{3 - 5 \%}$ & 3,944 & 3,465 & 3,371 & 2,058 & 0,600 \\
\hline VFB & Min. 65\% & 67,761 & 73,133 & 75,836 & 865,271 & 95,587 \\
\hline Stabilitas & $\begin{array}{c}\text { Min. 1800 } \\
\text { Kg }\end{array}$ & 2113,81 & 2219,05 & 2039,24 & 1995,43 & 1693,06 \\
\hline Flow & $\mathbf{3 - 6 ~ m m}$ & 3,93 & 4,13 & 4,53 & 5,97 & 6,38 \\
\hline MQ & Min. 300 & 544,24 & 537,77 & 456,89 & 351,11 & 266,85 \\
\hline
\end{tabular}

Sumber: Hasil Perhitungan

Keterangan:

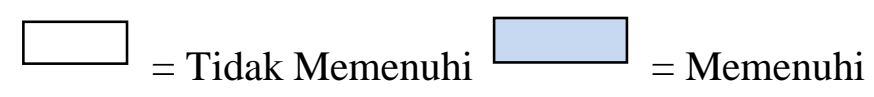

Dari tabel 2 didapatkan bahwa nilai KAO adalah sebesar 5,5\%.

\section{Pengaruh Ukuran Maksimum Terhadap Sifat Volumetrik dan Mekanik}

1) Pengaruh Ukuran Maksimum terhadap VIM

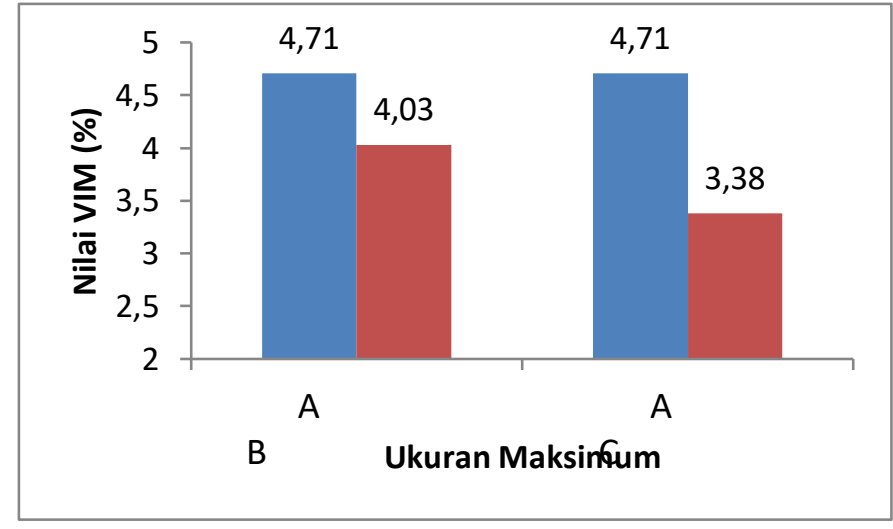

Gambar 1

Grafik hubungan antara ukuran maksimum dan VIM

Semakin besar ukuran maksimum agregat yang digunakan maka semakin kecil nilai VIM yang didapatkan. Benda uji A (1") menghasilkan nilai VIM yang lebih besar daripada benda uji B (1 1/2") dengan persentase agregat 1" sebesar 5\%. Sama halnya dengan benda uji A menghasilkan nilai VIM yang lebih tinggi dibanding benda uji C (1 1/2") dengan persentase agregat 1 " sebesar 10\%. Hal ini terjadi dikarenakan aspal yang dibutuhkan untuk menyelimuti agregat pada benda uji ukuran maksimum 1 1/2" lebih sedikit daripada benda uji ukuran maksimum 1". Sehingga lebih banyak aspal yang dapat mengisi rongga-rongga pada campuran benda uji B dan $\mathrm{C}$. 
Miftah Farid

2) Pengaruh Ukuran Maksimum terhadap VMA

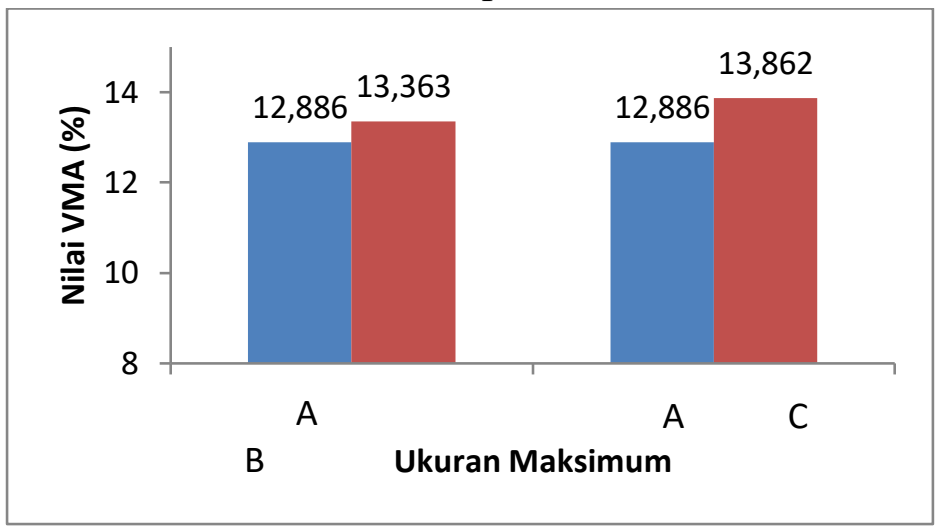

Gambar 2

Grafik hubungan antara ukuran maksimum dan VMA

Benda uji A (1") menghasilkan nilai VMA yang lebih kecil daripada benda uji B (1 1/2") dengan persentase agregat 1 " sebesar 5\%. Begitu juga benda uji A menghasilkan nilai VMA yang lebih rendah dibanding benda uji $\mathrm{C}(1$ 1/2") dengan persentase agregat 1 " sebesar 10\%. Hal ini terjadi dikarenakan benda uji A (1") memiliki distribusi butiran yang lebih kecil sehingga menghasilkan ruang antar agregat yang lebih kecil dibanding benda uji B dan C (1 1/2").

3) Pengaruh Ukuran Maksimum terhadap VFB

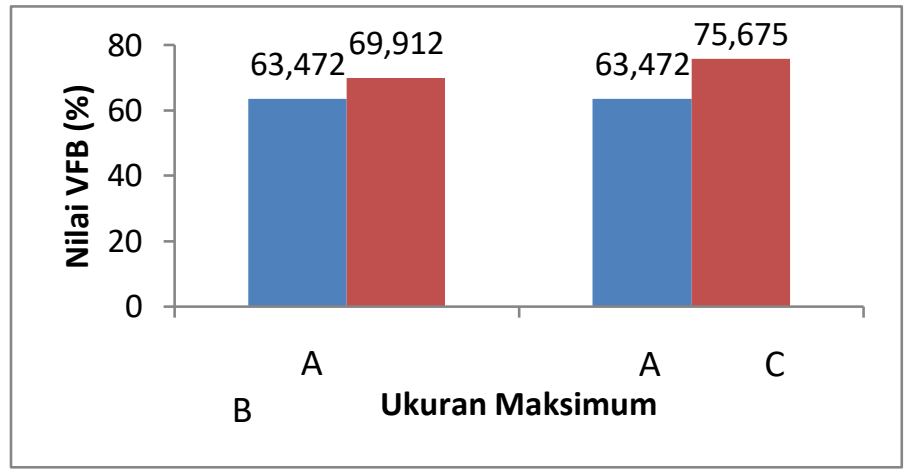

Gambar 3

Grafik hubungan antara ukuran maksimum dan VFB

Benda uji A (1") menghasilkan VFB yang lebih kecil daripada benda uji B (1 1/2") dengan persentase agregat 1" sebesar 5\%. Selain itu benda uji A juga menghasilkan VFB yang lebih rendah dibanding benda uji C (1 1/2") dengan persentase agregat 1" sebesar 10\%. Pada benda uji ukuran B dan C (1 1/2") membutuhkan aspal yang lebih sedikit untuk menyelimuti permukaan agregatnya jika dibandingkan dengan benda uji A (1"). Penggunaan agregat dengan ukuran lebih besar mengakibatkan terciptanya rongga antar agregat yang lebih besar daripada agregat yang menggunakan ukuran yang lebih kecil sehingga memudahkan aspal untuk masuk mengisi rongga-rongga yang ada. 
4) Pengaruh Ukuran Maksimum terhadap Density

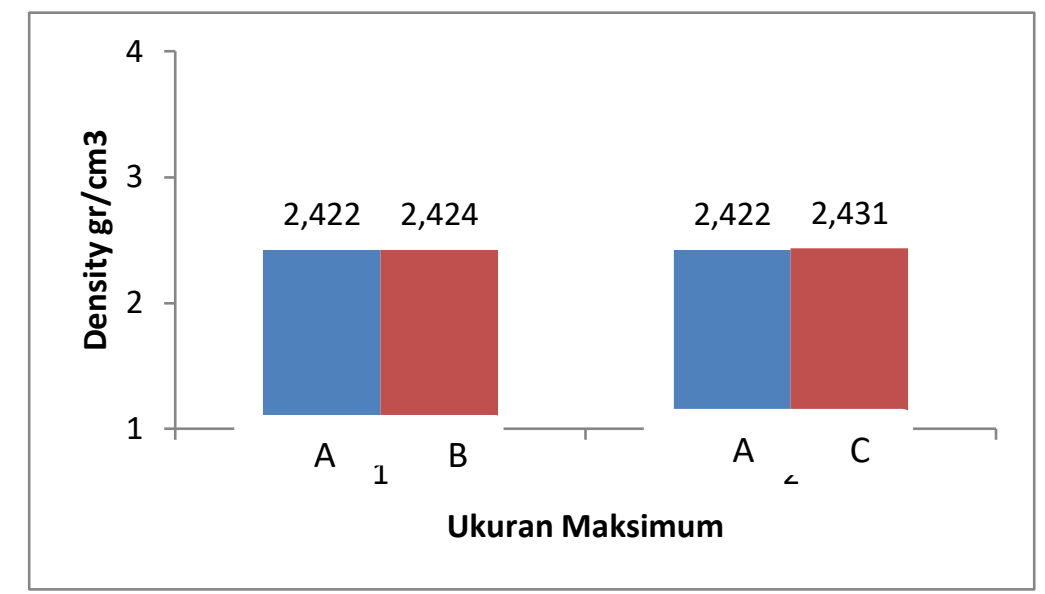

\section{Gambar 4}

Grafik hubungan antara ukuran maksimum dan density

Pada Gambar 4. terlihat bahwa nilai Density yang dihasilkan tidak jauh berbeda antara benda uji A (1") dengan benda uji B dan C (1 1/2"). Sehingga tidak terlihat adanya pengaruh yang berarti terhadap nilai Density dari campuran tersebut.

5) Pengaruh Ukuran Maksimum terhadap Stabilitas

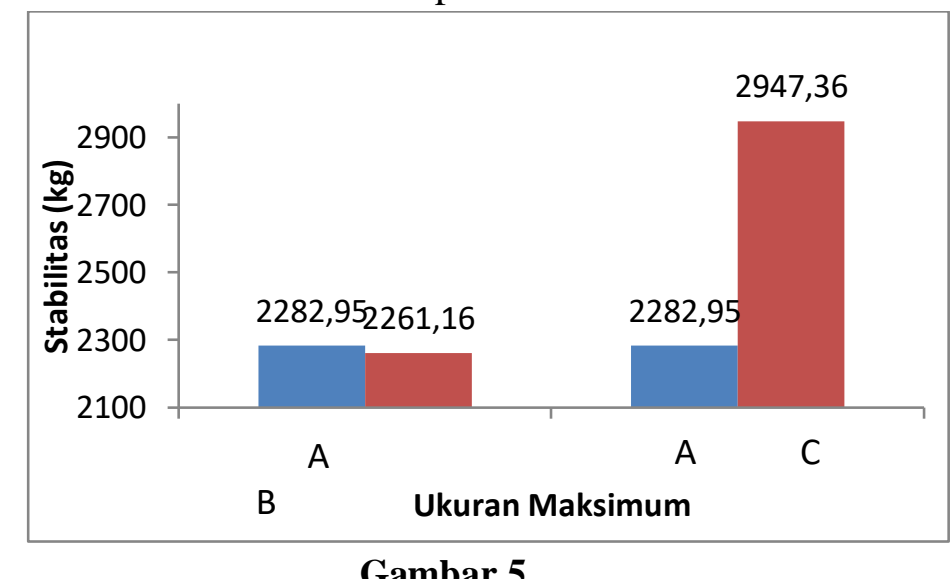

\section{Grafik hubungan antara ukuran maksimum dan stabilitas}

Benda uji C (1 1/2") dengan persentase agregat 1" sebesar 10\% menghasilkan stabilitas yang lebih tinggi dibandingkan benda uji A (1"). Hal ini dikarenakan penggunaan ukuran agregat yang lebih besar memberikan ketahanan yang lebih baik pada benda uji saat diberikan beban dari luar. Namun benda uji B (1 1/2") dengan persentase agregat 1" sebesar 5\% menghasilkan nilai stabilitas yang lebih rendah dari benda uji A. Hal ini terjadi karena penggunaan agregat ukuran 3/4" yang lebih banyak pada benda uji A menghasilkan interlocking antar agregat yang lebih baik dikarenakan agregat yang lebih seragam. 
6) Pengaruh Ukuran Maksimum terhadap Flow

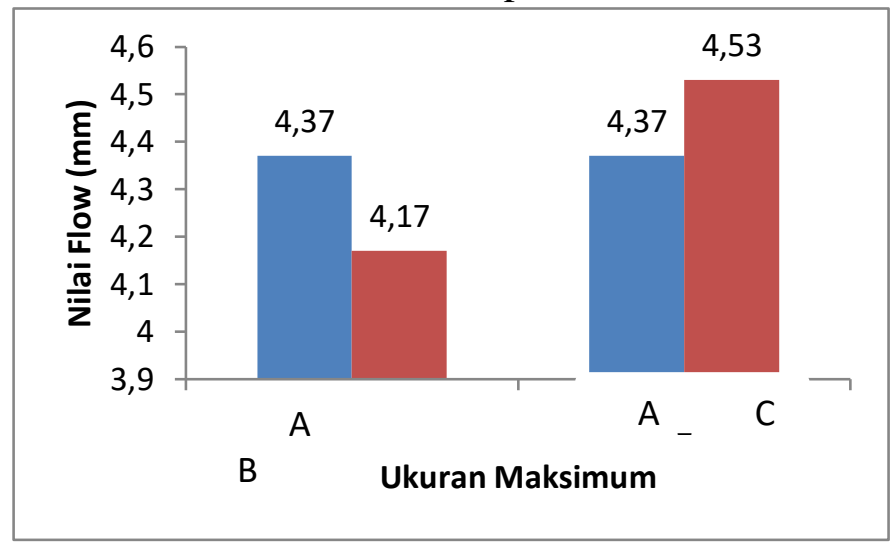

Gambar 6

Grafik hubungan antara ukuran maksimum dan flow

Pada Gambar 6. terlihat bahwa benda uji C (1 1/2") dengan persentase agregat 1" sebesar 10\% menghasilkan flow yang lebih tinggi dibandingkan benda uji A (1"). Hal ini terjadi dikarenakan benda uji C memiliki nilai VIM paling kecil dan VMA yang paling besar sehingga menyebabkan campuran menjadi lebih fleksibel dibanding benda uji A. Namun benda uji B ( $11 / 2$ ") dengan persentase agregat 1 " sebesar 5\% menghasilkan nilai flow yang lebih rendah dari benda uji A dikarenakan penggunaan agregat ukuran 3/4" yang lebih banyak pada benda uji A menghasilkan campuran yang lebih baik dalam daya ikat antar agregat dikarenakan penggunaan agregat yang lebih seragam.

7) Pengaruh Ukuran Maksimum terhadap $M Q$

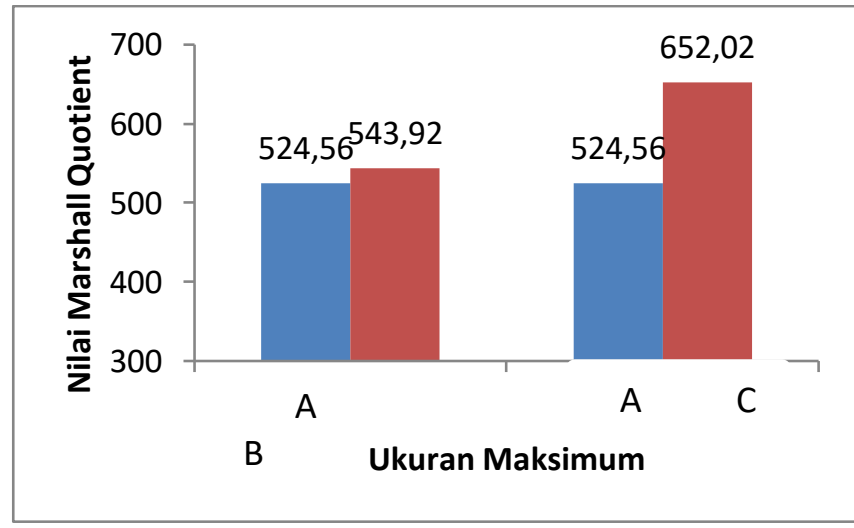

Gambar 7

Grafik hubungan antara ukuran maksimum dan $M Q$

Pada Gambar 7. terlihat bahwa benda uji B (1 1/2") dengan persentase agregat 1" sebesar 5\% menghasilkan nilai $M Q$ yang lebih besar dibandingkan benda uji A (1"). Sama halnya dengan benda uji C (1 1/2") dengan persentase 
agregat 1" sebesar 10\% menghasilkan $M Q$ yang lebih tinggi dibandingkan benda uji A.

Dari kedua parameter sifat di atas dapat disimpulkan bahwa benda uji C laston jenis ac-base yang menggunakan ukuran maksimum 1 1/2" dengan persentase agregat 1" sebesar 10\% menunjukkan kinerja yang paling baik dibanding benda uji B dengan perbedaan nilai stabilitas yang sangat mencolok. Hasil campuran yang memiliki stabilitas yang tinggi didapat jika digunakan ukuran maksimum agregat yang lebih besar namun dengan hasil permukaan yang kasar. Sebaliknya hasil campuran yang memiliki struktur permukaan yang lebih halus agar mengurangi efek keausan pada ban kendaraan didapat jika digunakan ukuran maksimum agregat yang lebih kecil.

8) Pengaruh Ukuran Maksimum terhadap IDT

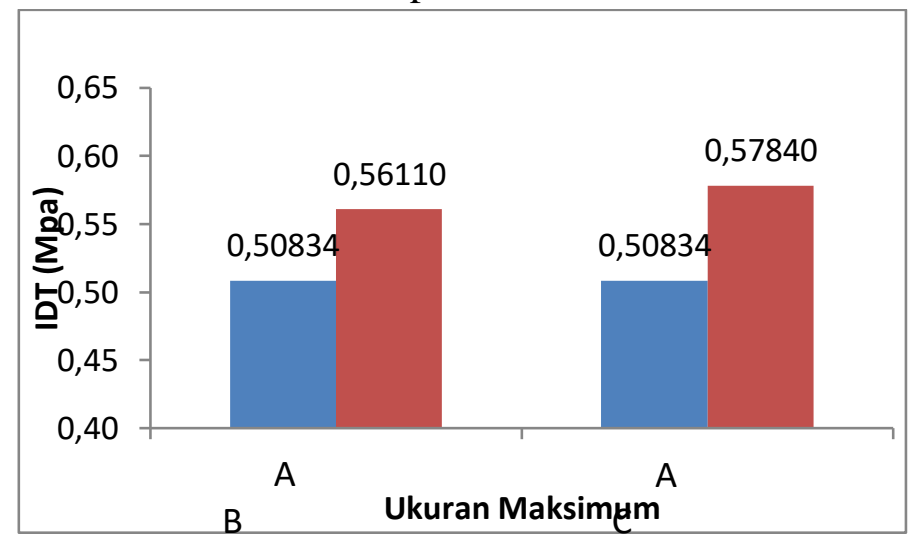

Gambar 8

Grafik hubungan antara ukuran maksimum dan IDT

Pada Gambar 8. terlihat terlihat benda uji A (1") menghasilkan nilai ITS yang lebih kecil daripada benda uji B (1 1/2") dengan persentase agregat 1" sebesar 5\%. Selain itu benda uji A juga menghasilkan nilai ITS yang lebih rendah dibanding benda uji C (1 1/2") dengan persentase agregat 1" sebesar $10 \%$. Hal ini dikarenakan penggunaan ukuran agregat yang lebih besar mampu memberikan ketahanan yang lebih baik saat mempertahankan ikatan antar agregat dengan aspal terhadap beban yang diterimanya. 
Miftah Farid

9) Pengaruh Ukuran Maksimum terhadap Stiffness Vertikal

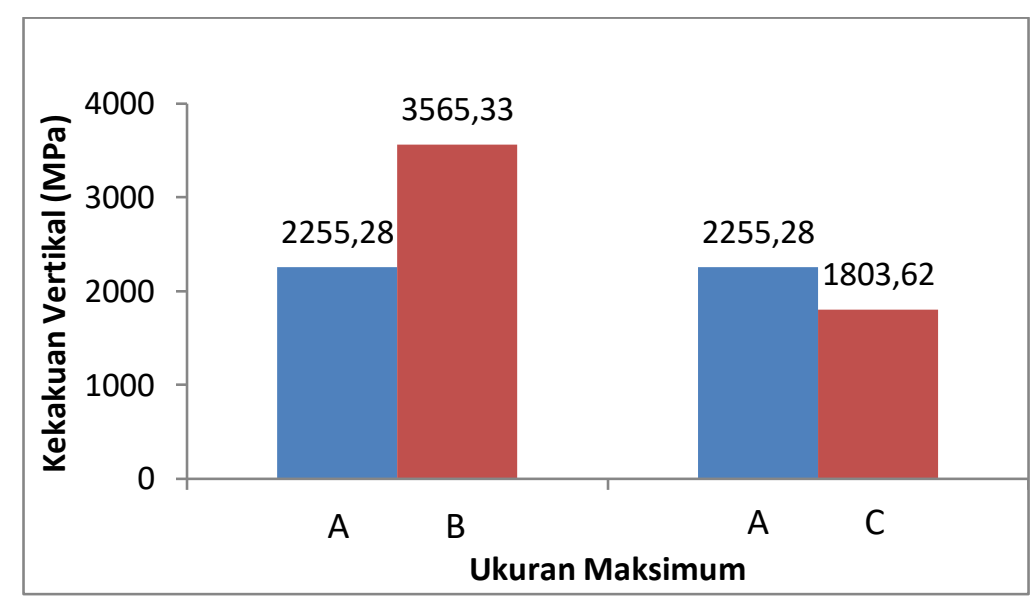

Gambar 9

Grafik hubungan antara ukuran maksimum dan kekakuan vertikal

Pada Gambar 9. terlihat bahwa benda uji C (1 1/2") dengan persentase agregat 1" sebesar 10\% menghasilkan nilai kekakuan vertikal yang lebih kecil dibanding benda uji A ( 1 "). Namun benda uji B ( 1 1/2") dengan persentase agregat 1" sebesar 5\% menghasilkan nilai kekakuan vertikal yang lebih tinggi dibanding benda uji A.

10) Pengaruh Ukuran Maksimum terhadap Stiffness Horizontal

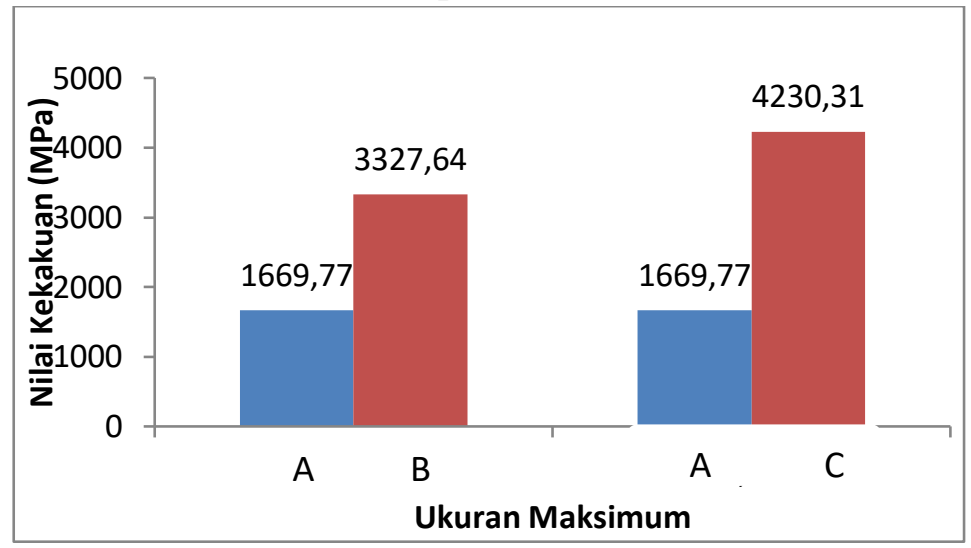

Gambar 10

Grafik hubungan antara ukuran maksimum dan kekakuan horizontal

Dari Gambar 10. terlihat benda uji A dengan (1") menghasilkan nilai kekakuan horizontal yang lebih kecil dibandingkan benda uji B (1 1/2") dengan persentase agregat 1" sebesar 5\%. Sama halnya benda uji A juga menghasilkan nilai kekakuan horizontal yang lebih rendah dibanding benda uji C ( $11 / 2$ ") dengan persentase agregat 1 " sebesar $10 \%$. 


\section{Kesimpulan}

Pertama, Benda uji laston jenis AC-Base yang menggunakan ukuran maksimum 1 $1 / 2$ " dengan persentase agregat 1 " sebesar $10 \%$ menunjukkan kinerja yang paling baik jika dilihat dari karakteristik volumetrik, mekanisnya, ITS, dan uji stiffness. Kedua, Jika menginginkan hasil campuran yang memiliki stabilitas yang tinggi maka digunakan ukuran maksimum agregat yang lebih besar namun dengan hasil permukaan yang kasar. Sebaliknya jika menginginkan campuran dengan hasil yang memiliki struktur permukaan yang lebih halus agar mengurangi efek keausan pada ban kendaraan maka digunakan ukuran maksimum agregat yang lebih kecil. 


\section{BIBLIOGRAFI}

Arfan, I. A. (2018). Studi Eksperimental Penentuan Kadar Aspal Buton Optimum Tipe Lga 50/30 Menggunakan Agregat Batu Gamping. Makassar.

Dewi, L. K., \& Landra, P. T. C. (2019). Perlindungan Produk-Produk Berpotensi Hak Kekayaan Intelektual Melalui Indikasi Geografis. Kertha Semaya: Journal Ilmu Hukum, 7(3), 1-17.

Gardjito, E., Candra, A. I., \& Cahyo, Y. (2018). Pengaruh Penambahan Batu Karang Sebagai Substitusi Agregat Halus Dalampembuatan Paving Block. UKaRsT, 2(1), 36.

Khonado, M. F., Manalip, H., \& Wallah, S. E. (2019). Kuat Tekan Dan Permeabilitas Beton Porous Dengan Variasi Ukuran Agregat. Jurnal Sipil Statik, 7(3).

Rahman, A., Djuniati, S., \& Wibisono, G. (2017). Pengaruh Pasir Pulau Bungin Kabupaten Kuantan Singingi pada Campuran Laston Lapis Fondasi/Asphalt Concrete Base (AC-BASE). Riau University.

Saleh, A. (2018). Pengaruh Penggunaan Zeolit Alam Sebagai Filler Pada Campuran AcBc Ditinjau Dari Nilai Vitm. Program Studi Teknik Sipil, 4(1), 36-42.

Situmorang, A. (2015). Variasi Jumlah Tumbukan Terhadap Uji Karakteristik Marsahall Untuk Campuran Laston (AC-BC).

Sukirman, S. (2016). Beton Aspal Campuran Panas. Institut Teknologi Nasional.

Toruan, A. L., Kaseke, O. H., Kereh, L. F., \& Sendow, T. K. (2013). Pengaruh porositas agregat terhadap berat jenis maksimum campuran. Jurnal Sipil Statik, 1(3).

Waani, J. E. (2013). Evaluasi Volumetrik Marshall Campuran AC-BC (Studi Kasus Material Agregat di Manado dan Minahasa). Jurnal Teknik Sipil ITB, 20(1), 67-78. 